\title{
Effect of liquid-phase surface tension on hydrodynamics of a three-phase airlift reactor with an enlarged degassing zone
}

\author{
Carla Freitas, José A. Teixeira
}

\begin{abstract}
The effect of the addition of ethanol $(10 \mathrm{~g} / \mathrm{l})$ to the liquid-phase on gas and solids holdup, circulation and mixing times and interstitial liquid velocity in a threephase airlift reactor was investigated. The airlift reactor $(60 \mathrm{l})$ is of the concentric draught-tube type with an enlarged degassing zone. Ca-alginate beads were used as solid-phase and airflow rate (from 1.9 to $90.2 \mathrm{l} / \mathrm{min}$ ) and solids loading $(0-30 \%(\mathrm{v} / \mathrm{v}))$ were manipulated. Riser and downcomer gas holdup were found to increase with the addition of ethanol, leading to a decrease on the relative solids holdup. The presence of ethanol seems to have no influence on the circulation time. On the other hand, mixing time variation depends on the solids loading and airflow rate. Riser and downcomer interstitial liquid velocity are lower for ethanol solution than for water.
\end{abstract}

\begin{tabular}{|c|c|}
\hline \multicolumn{2}{|c|}{ List of symbols } \\
\hline$A_{\mathrm{d}}$ & downcomer cross-section area $(\mathrm{m})$ \\
\hline$A_{\mathrm{r}}$ & riser cross-section area $(\mathrm{m})$ \\
\hline & $\begin{array}{l}\text { vertical distance between two points of the riser } \\
\text { and of the downcomer (m) }\end{array}$ \\
\hline$H_{1}-H_{2}$ & $\begin{array}{l}\text { pressure difference between two points of the } \\
\text { riser and of the downcomer }\left(\mathrm{cmH}_{2} \mathrm{O}\right)\end{array}$ \\
\hline$t_{\mathrm{c}}$ & circulation time $(\mathrm{s})$ \\
\hline$t_{\mathrm{m}}$ & ne (s) \\
\hline$u_{\mathrm{ld}}$ & er interstitial liquid velocity $(\mathrm{m} / \mathrm{s})$ \\
\hline$u_{\mathrm{li}}$ & al liquid velocity in section $\mathrm{i}(\mathrm{m} / \mathrm{s})$ \\
\hline$u_{\mathrm{lr}}$ & riser interstitial liquid velocity $(\mathrm{m} / \mathrm{s})$ \\
\hline$v_{\mathrm{gr}}$ & riser superficial gas velocity $(\mathrm{m} / \mathrm{s})$ \\
\hline$V_{\mathrm{s}}$ & solids volume measured in each sample (l) \\
\hline$V_{\mathrm{T}}$ & sample total volume (l) \\
\hline$\Delta t$ & $\begin{array}{l}\text { time required by the tracer to travel between the } \\
\text { two acquisition points in the riser and in the } \\
\text { downcomer (s) }\end{array}$ \\
\hline & downcomer gas holdup \\
\hline
\end{tabular}

Received: 5 January 1998

C. Freitas, J.A. Teixeira

I. B. Q. F. (Instituto de Biotecnologia e Química Fina)

Departamento de Engenharia Biológica, Universidade do Minho, Campus de Gualtar, 4709 Braga codex, Portugal

Tel.: +351 53 604400; Fax: +351 53678986

Corresponence to: J.A. Teixeira

This work was supported by J.N.I.C.T (Junta Nacional de Investigação Científica e Tecnológica) under project PRAXIS/2/2.1/ $\mathrm{BIO} / 1061 / 95$ and grant GGP XXI/BD/2937/96 awarded to Carla Maria Duarte de Freitas gas holdup in section $\mathrm{i}$

riser gas holdup

downcomer solids holdup

solids holdup in section i

riser solids holdup

liquid density $\left(\mathrm{kg} / \mathrm{m}^{3}\right)$

solids density $\left(\mathrm{kg} / \mathrm{m}^{3}\right)$
1

\section{Introduction}

Airlift reactors are especially useful for operations requiring solid-suspension without high shear force (e.g. fermentation and cell culture). Fermentation broths are complex mixture of cells, sugars, electrolytes, proteins, etc. and exhibit high viscosity, low surface tension and nonNewtonian characteristics [1]. However, the majority of hydrodynamic data for airlift reactors has been obtained with air/water systems, with properties different from the real conditions of operation. It is, nevertheless, known that both liquid viscosity and surface tension affect gas holdup. The small bubbles formed in liquids with reduced surface tension may enhance gas holdup. Snape et al. [2] used several salt solutions as well as sucrose solutions in concentrations typical of fermentation media and measured gas holdup and liquid velocity. They found that low sugar concentrations cause an increase in gas holdup but higher concentrations lead to a lower value. This is due to the fact that the increase of sugar concentration has several effects on the physical properties of the liquid-phase: the density and the viscosity of the solution increase but the surface tension decreases slightly. Also, the liquid velocity was influenced by the sugar concentration at low airflow rates.

It is considered that dilute aqueous alcohol solutions simulate reasonably well the liquid-phase behaviour in bioreactors [3], the surface tension being the only physical property which differs significantly from water. Aqueous solutions of ethanol represent a coalescence inhibiting system, which will affect bubble size and the overall hydrodynamics. Kennard and Janekeh [4] tested the effect of several additives on the mean bubble size, in a concentric draft tube gas-lift fermenter. They found that ethanol is the one who has the greatest effect and that the mean bubble diameter increases with surface tension by a power of 3.5. Bigger bubbles have higher velocities, what results in lower gas holdup. Wachi et al. [1] observed that ethanol and glycerol increase the gas holdup inside the draft tube, enhance the entrance of gas bubbles into the downcomer and inhibit liquid circulation, when compared with pure water. The influence of alcohols on gas holdup depends on their 
concentration and on the length of the carbon chain. Increasing alcohol concentration, the coalescence decreases (gas holdup increases) but only up to a limiting concentration value above which further increases of the alcohol concentration have no influence on gas holdup. Zahradník et al. [5] found for ethanol a limiting concentration of $0.11 \mathrm{~mol} / \mathrm{l}$, agreeing with the transition coalescence concentration $(0.14 \mathrm{~mol} / \mathrm{l})$ reported for ethanol solutions by Oolman and Blanch [6]. Kennard and Janekeh [4] found that ethanol decreases bubble diameter up to a concentration of about $2 \mathrm{~g} / \mathrm{l}$; a further increase of ethanol concentration has little consequence on bubble size. Kelkar et al. [3] and Zahradník et al. [5] observed that the increase of alcohol chain length, in dilute aqueous solutions of aliphatic alcohols, leads to a considerable increase in the gas holdup, decreasing the transition coalescence concentration.

Since gas holdup induces liquid velocity which, in turn, affects mixing, it is expected that these parameters change with surface tension too. Although the effects of fluid properties on gas holdup and liquid velocity have been investigated [1-3] their influence on the behaviour of a three-phase system has not been fully studied.

The aim of this study is to compare the behaviour of a three-phase airlift reactor with an enlarged degassing zone when water and an aqueous solution of ethanol are used as liquid-phase. The concentration of ethanol used $(10 \mathrm{~g} / \mathrm{l})$ is higher than the limiting concentration $(0.11 \mathrm{~mol} / \mathrm{l}) \mathrm{re}$ ported by Zahradník et al. [5], in order to observe the maximum deviation possible. Gas and solids holdup in the riser and in the downcomer, circulation and mixing times and riser and downcomer interstitial liquid velocity were measured for both liquid-phases, changing solids loading and airflow rate.

\section{2}

\section{Materials and methods}

\section{1}

\section{The reactor}

A 601 airlift reactor of the concentric draught tube type, with an enlarged degassing zone was used (Fig. 1). It is made of Plexiglas with a thickness of $8 \mathrm{~mm}$. The total height of the reactor is $1.986 \mathrm{~m}$ and the fluid level is $0.530 \mathrm{~m}$ above the top of the draught tube. The height and the diameter of the downcomer are $1.190 \mathrm{~m}$ and $0.142 \mathrm{~m}$, respectively. The draught tube height and diameter are, respectively, $1.190 \mathrm{~m}$ and $0.062 \mathrm{~m}$ and its bottom edge is $0.086 \mathrm{~m}$ above the bottom of the reactor.

The top section is of the cylindrical conical type. The conical section forms a $51^{\circ}$ angle with the main body of the reactor and the height and diameter of the cylindrical part are, respectively, $0.350 \mathrm{~m}$ and $0.442 \mathrm{~m}$.

A $0.030 \mathrm{~m}$ circular distribution plate, with 30 holes of $1 \mathrm{~mm}$ each, is used to inject air. It is placed $0.061 \mathrm{~m}$ below the bottom of the draught tube.

\section{2}

\section{Gas-liquid-solid system}

Air was used as gas-phase and airflow rate was adjusted to $1.9,5.5,9.1,13.6,30.3,58.8$ and $90.2 \mathrm{l} / \mathrm{min}$. The riser superficial gas velocity $\left(v_{\mathrm{gr}}\right)$ was calculated as the ratio be- tween the air volumetric flow rate and the riser crosssection area.

Water and a $10 \mathrm{~g} / \mathrm{l}$ aqueous solution of ethanol were used as liquid-phase.

Ca-alginate beads were used as solid-phase and were prepared according to the procedure described by Vicente and Teixeira [7]. The mean diameter and density were $2.131 \pm 0.102 \mathrm{~mm}$ and $1023 \pm 1 \mathrm{~kg} / \mathrm{m}^{3}$, respectively.

Solids loading studied was 5\%,10\%,15\%,20\% and $30 \%$ $(\mathrm{v} / \mathrm{v})$.

\section{5}

\section{Solids holdup determination}

Solids holdup was measured at the top of the riser and of the downcomer, by sampling the gas-liquid-solid slurry.

The sampler is a $60 \mathrm{ml}\left(V_{\mathrm{T}}\right)$ cylinder with two valves at the top and at the bottom [8]. When it was introduced into the reactor, the valves were opened in the flow direction and, for sample collection, they were closed simultaneously. In each sample, solids volume $\left(V_{s}\right)$ was measured. With this value, solids holdup in riser and in downcomer $\left(\varepsilon_{\mathrm{si}}\right)$ was calculated:

$\varepsilon_{\mathrm{si}}=\frac{V_{\mathrm{s}}}{V_{\mathrm{T}}}$.

For each set of experimental conditions, three samples were taken.

\section{6}

\section{Gas holdup determination}

Gas holdup was determined for the riser $\left(\varepsilon_{\mathrm{gr}}\right)$ and the downcomer $\left(\varepsilon_{\mathrm{gd}}\right)$ by measuring the pressure difference between the top and the bottom of both the riser and the downcomer, with a differential pressure transducer connected to a data acquisition system linked to a personal computer. In each section, the distance between the two pressure acquisition points is $d=1.09 \mathrm{~m}$ (see Fig. 1). Two pressure transducers - P3061-2WD and P3061-5WD, LCSP Shaevitz ${ }^{\mathrm{TM}}$ Pressure Sensors - for different working ranges $\left(0-5\right.$ and $\left.0-13 \mathrm{cmH}_{2} \mathrm{O}\right)$ were used. For each set of experimental conditions, different pressure differences $\left(H_{1}-H_{2}\right)$ in the riser and in the downcomer were measured three times, during $300 \mathrm{~s}$ each. The mean of the registered values was used for the calculation of gas holdup, for each section (i) of the reactor, by the equation:

$\varepsilon_{\mathrm{gi}}=\frac{\left(H_{1}-H_{2}\right)_{\mathrm{i}}}{d}-\frac{\rho_{1}-\rho_{\mathrm{s}}}{\rho_{1}} \times \varepsilon_{\mathrm{si}}$.

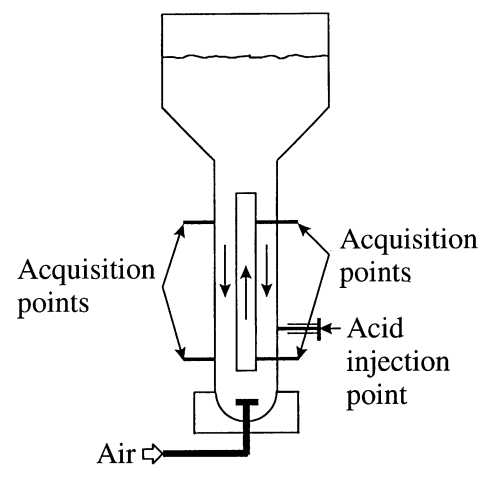

Fig. 1. Airlift reactor 


\section{7}

\section{Liquid phase characterisation}

Liquid phase circulation and mixing times and liquid velocity were determined by the $\mathrm{pH}$ pulse technique. Four $\mathrm{pH}$ sensors were placed in the top and in the bottom of the riser and of the downcomer, $0.136 \mathrm{~m}$ and $1.226 \mathrm{~m}$ above the bottom of the reactor, respectively (see Fig. 1). The signals of all $\mathrm{pH}$ sensors were transmitted to a computer by a data acquisition system (PCL-812PG Enhanced MultiLab Card, Advantech Co, Ltd). For each set of experimental conditions, the $\mathrm{pH}$ was first increased to a value around 10 by adding, at the top of the reactor, a sodium hydroxide solution $\left(10 \mathrm{~mol} / \mathrm{dm}^{3}\right)$. After stabilisation of the $\mathrm{pH}$ value, a pulse of $2.5 \mathrm{ml}$ sulphuric acid $\left(4.5 \mathrm{~mol} / \mathrm{dm}^{3}\right)$ was injected into the downcomer, $0.236 \mathrm{~m}$ above the bottom of the reactor, at time zero. The data acquisition was stopped once a constant $\mathrm{pH}$ value was achieved. Three replicates were made for each set of experimental conditions and, at the end of each experiment, the reactor was emptied and the alginate beads were washed in order to minimise their turgescence caused by extreme $\mathrm{pH}$ conditions.

\subsection{1}

\section{Mixing and circulation times}

Mixing time $\left(t_{\mathrm{m}}\right)$ was determined as the time required for the variation of the $\mathrm{pH}$ value to be within $5 \%$ of the final equilibrium value.

The circulation time $\left(t_{c}\right)$ was computed by averaging the time spans between maximum consecutive $\mathrm{pH}$ peaks in the $\mathrm{pH}$ response curve.
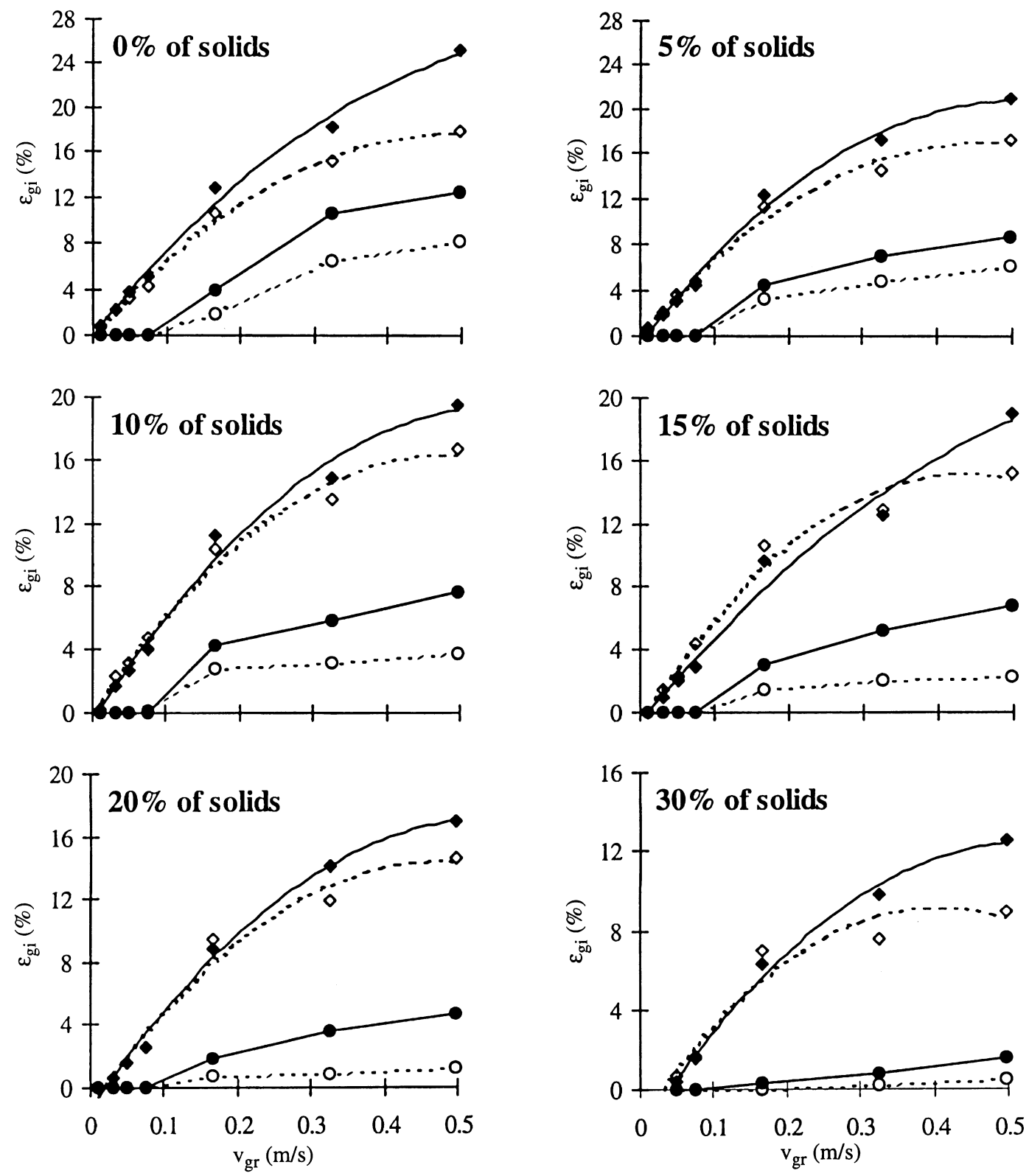

Fig. 2. Riser and downcomer gas holdup for aqueous solution of ethanol and for water versus the riser superficial gas velocity, for all the solids loading studied ( $\bullet$ - Riser/Ethanol; $\diamond-$ Riser/ Water; - Downcomer/Ethanol; $\bigcirc$ - Downcomer/Water) 
Mixing and circulation times were obtained independently for each of the four electrodes. Their final values, for each set of experimental conditions, are the average between the values registered by the four electrodes in the three replicates made.

\subsection{2}

\section{Interstitial liquid velocity}

The downcomer liquid velocity $\left(u_{\mathrm{ld}}\right)$ was calculated directly from the peaks of the signals obtained by the two electrodes located in the downcomer, by knowing the time $(\Delta t)$ required by the tracer to travel from one to the other (distance $d$ of $1.09 \mathrm{~m}$ ):

$u_{\mathrm{ld}}=\frac{d}{\Delta t\left(1-\varepsilon_{\mathrm{gd}}-\varepsilon_{\mathrm{sd}}\right)}$.

As turbulence and backmixing were more intense in the riser than in the downcomer, the interstitial liquid velocity in the riser $\left(u_{l r}\right)$ was calculated:

$u_{\mathrm{lr}}=u_{\mathrm{ld}} \times \frac{A_{\mathrm{d}}}{A_{\mathrm{r}}} \times \frac{\left(1-\varepsilon_{\mathrm{gd}}-\varepsilon_{\mathrm{sd}}\right)}{\left(1-\varepsilon_{\mathrm{gr}}-\varepsilon_{\mathrm{sr}}\right)}$.

\section{3}

\section{Results and discussion}

The influence of the liquid-phase properties on riser and downcomer gas holdup, for all riser superficial gas velocities and solids loading, is presented in Fig. 2. The addition of ethanol increases both riser and downcomer gas holdup, for all solids loading and airflow rates, with the exception of low airflow rates. For these, air does not enter the downcomer and the downcomer gas holdup is zero, meaning that rising bubbles velocity is higher than the descending liquid velocity. Ethanol is known to reduce the mean bubble size by inhibiting bubble coalescence [1], since the surface tension decreases. This, in turn, enhances the entrance of gas bubbles into the downcomer, due to the reduced gas-liquid slip velocity of the smaller gas bubbles. The importance of the reduction in surface tension in the increase of gas holdup shown is consistent with the results presented by Wachi et al. [1] and by Snape et al. [2]. Hikita et al. [9] showed that the gas holdup in a bubble column was proportional to the liquid-phase surface tension to the power of $-2 / 3$.

It is also evident from Fig. 2 that the influence of ethanol is bigger for high airflow rates. In these conditions, collision between air bubbles is more intense and bubbles coalescence becomes increasingly significant, the surface tension being a major influence on this process. At low airflow rates, the liquid-phase surface tension has little effect on gas holdup. The amount of air into the reactor is small and the coalescence is not significant. So, the inhibition of coalescence by ethanol is not high enough to be relevant.

The result of the addition of ethanol on the riser and downcomer solids holdup, for different solids loading, is shown in Figs. 3 and 4. The influence of the airflow rate and of solids loading is similar for both liquid-phases. Nevertheless, solids holdup in the riser and in the downcomer is higher for water than for the aqueous solution of ethanol, resulting from the increase of the gas holdup in

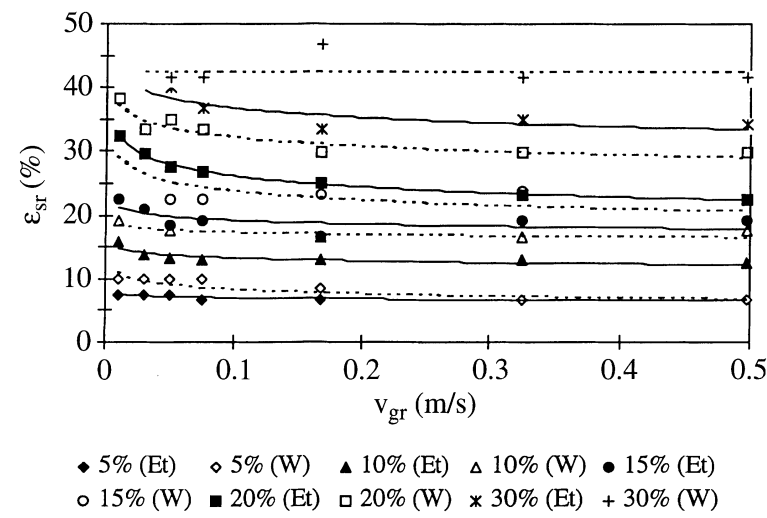

Fig. 3. Riser solids holdup for aqueous solution of ethanol and for water versus the riser superficial gas velocity, for all the solids loading studied (liquid-phase: aqueous solution of ethanol - Et and water - W)

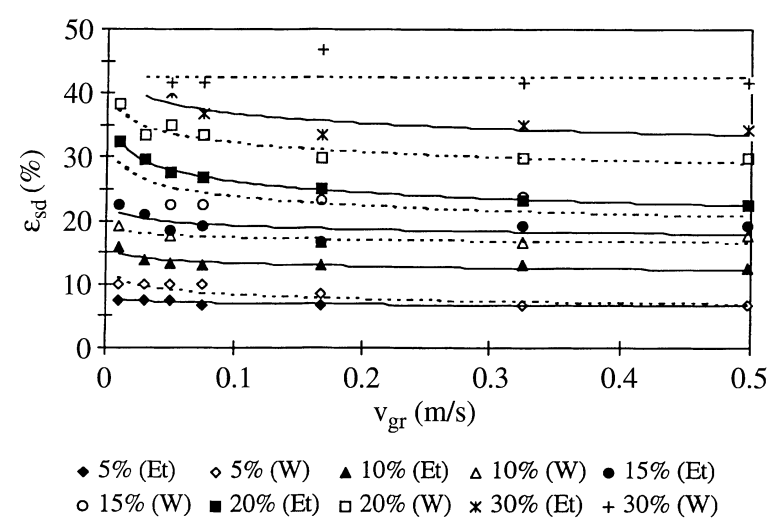

Fig. 4. Downcomer solids holdup for aqueous solution of ethanol and for water versus the riser superficial gas velocity, for all the solids loading studied (liquid-phase: aqueous solution of ethanol - Et - and water - W)

those sections of the reactor with the addition of ethanol (see Fig. 2).

The values of the circulation time measured for the aqueous solution of ethanol are similar to those found for water (Fig. 5). This happens because, as can be seen in Figs. 2, 3 and 4, the variations of gas and solids holdup in the riser with the addition of ethanol are of the same magnitude of the ones occurring in the downcomer. Thus, the difference between riser and downcomer fluid densities, which is in fact the driving force for liquid circulation, is not very affected, meaning that the circulation driving force is almost constant. This is the opposite of the results reported by Wachi et al. [1] who observed a decrease in liquid circulation rate for solutions of ethanol compared to water. However, these results were observed working with a two-phase system in a draft-tube bubble column without a degassing zone.

Figure 6 reports the influence of the addition of ethanol on the riser and downcomer interstitial liquid velocity. The interstitial liquid velocity is higher for water than for ethanol aqueous solution, especially in the riser. In spite of the increase of gas holdup, the lower riser and downcomer solids holdup observed for ethanol (Figs. 3 and 4) results in an increment of spaces through which liquid 

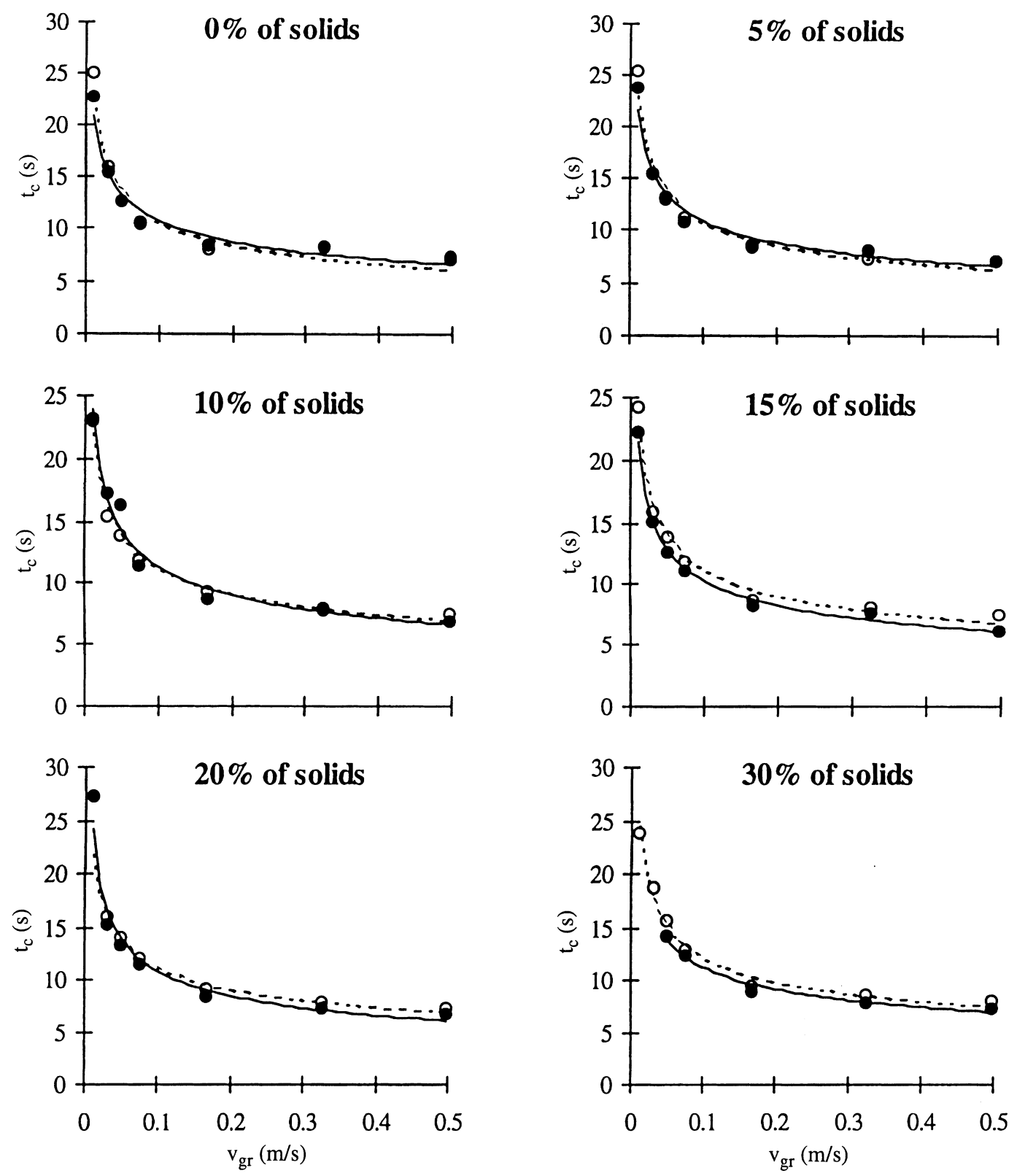

Fig. 5. Circulation time for aqueous solution of ethanol and for water versus the riser superficial gas velocity, for all the solids loading studied ( - Ethanol; $\bigcirc-$ Water)

flows, with the consequent decrease of the interstitial liquid velocity.

Observing Fig. 7, it can be seen that mixing time increases, in general, in the presence of ethanol. However, for high solids loading and, at the same time, low airflow rates, the opposite occurs that is, mixing time in water is higher than in ethanol solution. From the relation between mixing time and the riser superficial gas velocity $\left(t_{\mathrm{m}}=a v_{\mathrm{gr}}^{b}\right)$, while the $b$ value obtained for water presents similar values for all solids loading, for the aqueous solution of ethanol it decreases with the increase of solids loading. This shows the different way how solids loading acts on mixing when coalescence is inhibited. The overall mixing time is the result of the mixing observed in the several sections of the reactor. It is in the degassing zone above the draught tube that the most intense mixing occurs due to the ring vortices formed. However, since circulation time is almost the same for ethanol solution and for water (see Fig. 5), the same contribution of the degassing zone for the overall mixing is expected for both liquid-phases. So, mixing in the riser and in downcomer will probably be responsible for the differences observed. As the riser and downcomer cross-sectional areas are small, the amount of solids plays an important role on that. Usually, the higher the solids holdup in the riser and in the downcomer (with water, as can be seen in Fig. 3 and 4) the higher the turbulence what, associated to the higher bubble coalescence, improves mixing. That is why mixing time for water is, in general, lower. But, for high solids loading and low airflow rates, riser and downcomer solids holdup are specially high for 

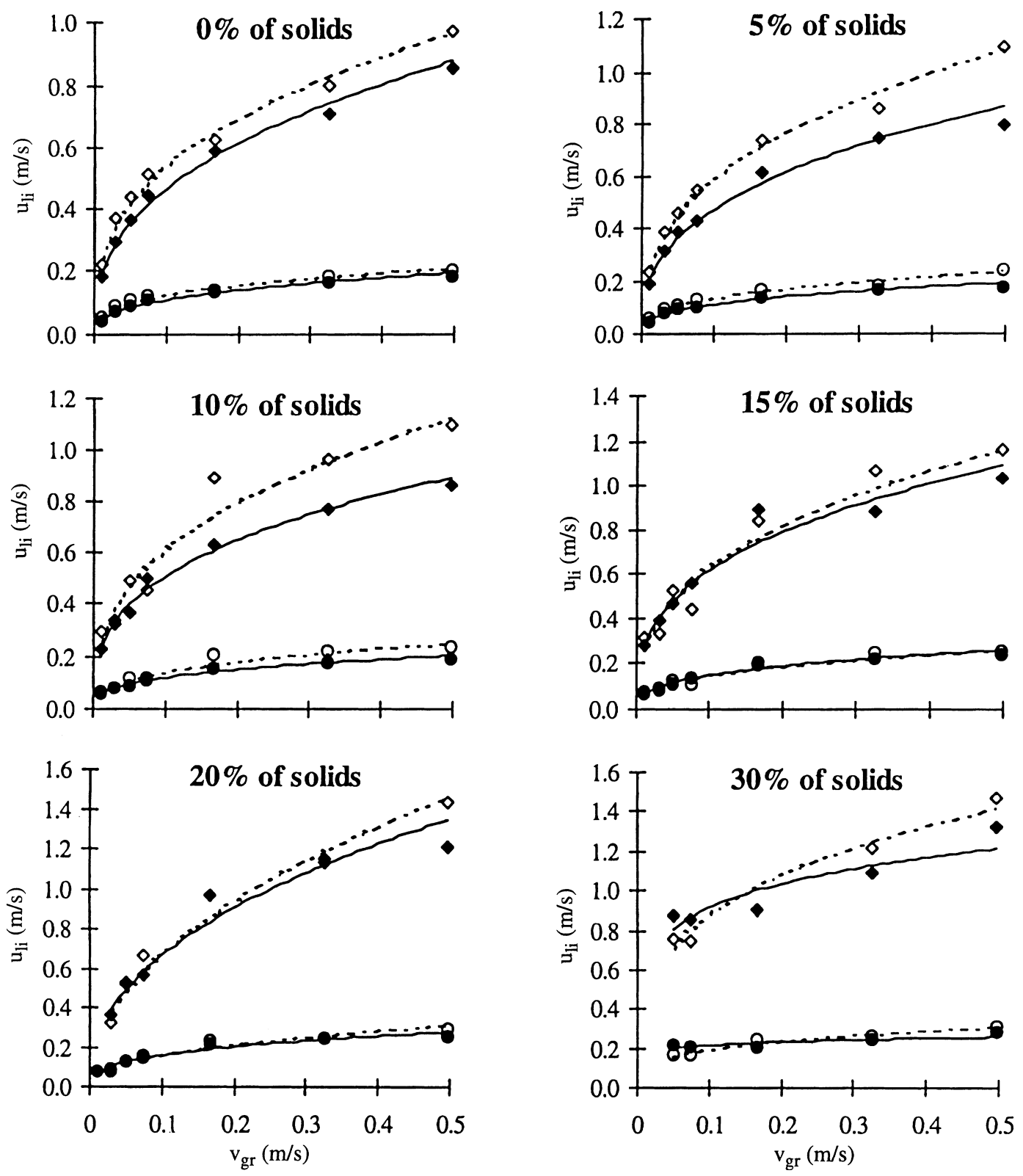

Fig. 6. Riser and downcomer interstitial liquid velocity for aqueous solution of ethanol and for water versus the riser superficial gas velocity, for all the solids loading studied ( $\bullet$ - Riser/ Ethanol; $\diamond$ - Riser/Water; - Downcomer/Ethanol; $\bigcirc$ -

Downcomer/Water)

water. Since there are few spaces for liquid to contact, mixing is more difficult and mixing time is higher. In this case, inhibition of coalescence may have the opposite effect to the one above described.

\section{4}

\section{Conclusions}

The gas and solids holdup in the riser and in the downcomer, the circulation and mixing times and the riser and downcomer interstitial liquid velocity were measured for water and for an aqueous solution of ethanol of $10 \mathrm{~g} / \mathrm{l}$, for various solids loading and airflow rates.

It can be concluded that the reduction in surface tension with the addition of ethanol has a great influence on the hydrodynamics of the airlift reactor. The primary consequence of the reduction in surface tension is the increase of riser gas holdup and the augment of the entrance of gas into the downcomer. Deriving from the increase of the riser and downcomer gas holdup a decrease of solids holdup in these sections is observed. However, the difference between gas and solids holdup in the riser and in the downcomer remains practically constant when ethanol is added. Consequently, due to the maintenance of the driving force for the circulation, the circulation time for the ethanol solution is similar to the one observed for water. The lower riser and downcomer solids holdup observed for ethanol causes a decrease of the riser and downcomer interstitial liquid velocity. With the exception 

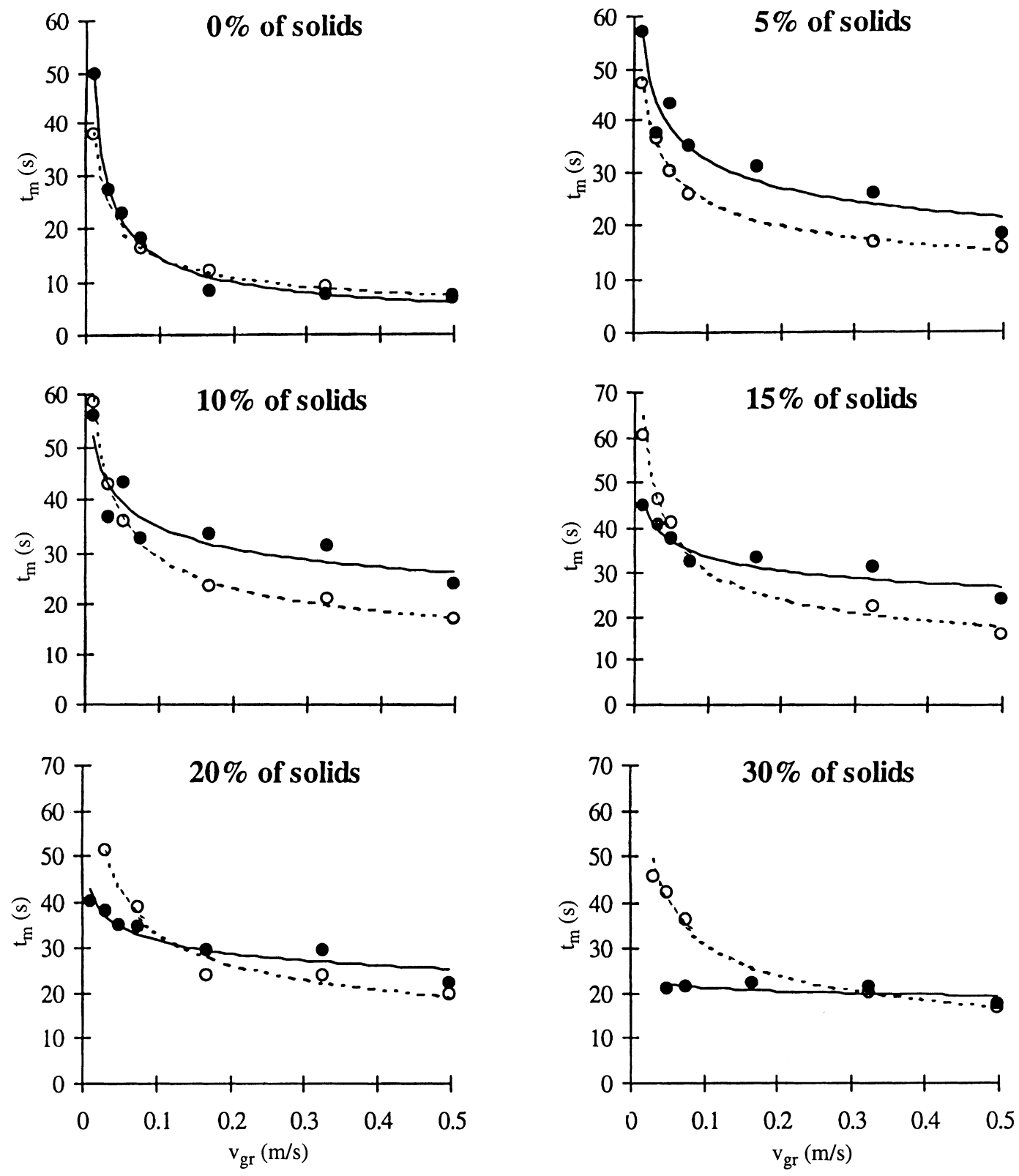

Fig. 7. Mixing time for aqueous solution of ethanol and for water versus the riser superficial gas velocity, for all the solids loading studied ( - Ethanol; $\bigcirc$ - Water)

of the high solids loading and the low airflow rates, the presence of ethanol in the liquid-phase increases the mixing time in the three-phase system.

\section{References}

1. Wachi, S.; Jones, A.G.; Elson, T.P.: Flow dynamics in a drafttube bubble column using various liquids. Chem. Eng. Science 46 (1991) 657-663

2. Snape, J.B.; Fialová, M.; Zahradník, J.; Thomas, N.H.: Hydrodynamic studies in an external loop airlift reactor containing aqueous electrolyte and sugar solutions. Chem. Eng. Science 47 (1992) 3387-3394

3. Kelkar, B.G.; Godbole, S.P.; Honath, M.F.; Shah, Y.T.; Carr, N.L.; Deckwer, W.-D.: Effect of addition of alcohols on gas holdup and backmixing in bubble columns. AIChE J. 29 (1983) 361-369
4. Kennard, M.; Janekeh, M.: Two- and three-phase mixing in a concentric draft tube gas-lift fermentor. Biotechnol. Bioeng. 38 (1991) 1261-1270

5. Zahradník, J.; Fialová, M.; Ruzicka, M.; Drahos, J.; Kastánek, F.; Thomas, N. H.: Duality of the gas-liquid flow regimes in bubble column reactors. In: 12th International Congress CHISA'96, Abstract P5.105, 63, Prague, 25-30 August (1997)

6. Oolman, T.O.; Blanch, H.W.: Bubble coalescence in stagnant liquids. Chem. Eng. Commun. 5 (1986) 69-72

7. Vicente, A.A.; Teixeira, J.A.: Hydrodynamic performance of a three-phase airlift bioreactor with an enlarged degassing zone. Bioprocess Eng. 14 (1995) 17-22

8. Freitas, C.; Vicente, A.A.; Mota, M.; Teixeira, J.A.: A new sampling device for measuring solids hold-up in a three-phase system. Biotechnol. Tech. 11 (1997) 489-492

9. Hikita, H.; Asai, S.; Tanigawa, K.; Kitao, M.: Gas holdup in bubble columns. Chem. Eng. J. 20 (1980) 59-67 